\title{
PESQUISA (AUTO)BIOGRÁFICA, EDUCAÇÃO E SAÚDE DOCENTE: escritas de formação e refiguração identitária ${ }^{1}$
}

\author{
Elizeu Clementino de Souza ${ }^{2}$ \\ Rosiane Costa de Sousa ${ }^{3}$
}

\begin{abstract}
Resumo
O texto sistematiza questões relacionadas à pesquisa (auto)biográfica no campo da Educação, centrando-se na discussão da escrita do diário como dispositivo de pesquisa-formação e suas implicações com condições de trabalho e adoecimento docente. Objetiva-se ampliar o debate sobre possibilidades do uso do método (auto)biográfico e desafios na contemporaneidade, especialmente, no que se refere ao fenômeno do adoecimento docente e a suas interfaces com o mundo do trabalho. Utilizamos como corpus de análise diários de cinco professores, analisando-os numa perspectiva interpretativa-compreensiva. As narrativas dos docentes, construídas nos diários, evidenciam experiências do adoecer e suas interfaces com condições objetivas e subjetivas do trabalho, inscritas num projeto de refiguração da vida-profissão, mediado pela escrita de si como dispositivo de resistência, de aprendizagens com a doença e disposições de cuidado de si.
\end{abstract}

Palavras-chave: Pesquisa (auto)biográfica. Educação. Saúde docente. Refiguração.

\section{(AUTO)BIOGRAPHICAL RESEARCH, EDUCATION AND TEACHER HEALTH: writings of formation and identity refiguration}

\begin{abstract}
The text systematizes issues related to (auto)biographical research in the field of education, focusing on the discussion of diary writing as a device for research-training and its implications for working conditions and teacher illness. The aim is to broaden the debate on the possibilities of using the (auto)biographical method and challenges in contemporary times, especially with regard to the phenomenon of teacher illness and its interfaces with the world of work. We used as corpus of analysis the diaries of five teachers, analysing them from an interpretativecomprehensive perspective. The teachers' narratives, constructed in the diaries, show experiences of getting sick and its interfaces with objective and subjective conditions of work, inscribed in a project of refiguration of life-profession, mediated by the writing of the self as a device of resistance, of learning with the disease and dispositions of self-care.
\end{abstract}

Keywords: (Auto)biographical research. Education. Teaching health. Refiguration.

\footnotetext{
${ }^{1} \mathrm{O}$ texto resulta de ações da pesquisa "Narrativas de adoecimento e aprendizagens biográficas: interfaces saúdedoença e vida-morte", financiada pelo Conselho Nacional de Desenvolvimento Científico e Tecnológico (CNPq), Processo $n^{\circ}$ 311890/2020-2 e da tese de doutorado de Sousa (2021) Refigurar a vida-profissão: (auto)biografia, condições de trabalho e adoecimento, sob a orientação de Elizeu Clementino de Souza.

${ }^{2}$ Pesquisador 1B do Conselho Nacional de Desenvolvimento Científico e Tecnológico (CNPq). Professor titular do Programa de Pós-Graduação em Educação e Contemporaneidade (PPGEduC) da Universidade do Estado da Bahia (UNEB). Coordenador do Grupo de Pesquisa (Auto)biografia, Formação e História Oral (GRAFHO) da UNEB. E-mail: esclementino@uol.com.br. ORCID: http://orcid.org/0000-0002-4145-1460.

${ }^{3}$ Professora da Rede Municipal de Valença (BA). Doutora em Educação pelo Programa de Pós-Graduação em Educação e Contemporaneidade (PPGEduC) da Universidade do Estado da Bahia (UNEB). Membro do Grupo de Pesquisa (Auto)biografia, Formação e História Oral (GRAFHO) da UNEB. E-mail: rosicsousa@ hotmail.com. ORCID: https://orcid.org/0000-0001-5573-1482.
} 


\section{Introdução}

O ato de pesquisar é acompanhado por incertezas, por dúvidas e escolhas epistêmicometodológicas, implicando caminhos, bifurcações, descobertas e aventuras. Pesquisar é uma aventura incrível! Uma experiência de vida-formação, um movimento pendular, de apropriações de conceitos, de verticalização do objeto e de aproximações com o cotidiano que se pesquisa.

Seja como for, as incertezas, longe de ser o problema do pesquisador, são a base que ancoram ideias que surgem titubeando, que a todos parecem confusas, desnecessárias. Contudo, você sabe a força que elas possuem, a potência que carregam, então arriscar-se é um dos caminhos. São essas incertezas que te levam a um árduo processo de investigação. Certamente terá de fazer escolhas difíceis, muitas vezes se sentirá incompreendido, mas todos os investimentos são fundamentais para formação do pesquisador e sua vinculação e aderência a um campo de estudo.

O pesquisador, portanto, necessita enxergar e escutar bem o problema que apresenta. $\mathrm{E}$ precisa ter implicação e saber-se dele distanciar-se. Olhar por diversos ângulos, até que entenda qual caminho metodológico seguir. Se após esse exame concluir que o método (auto)biográfico é o que mais se alinha com a pesquisa, então cabe responder por que trabalhar com narrativas como prática de pesquisa-formação e qual ou quais dispositivos metodológicos para acessá-las.

Nossa intenção neste texto é sistematiza questões relacionadas à pesquisa (auto)biográfica no campo da Educação (DELORY-MOMBERGER, 2014), centrando-se na discussão da escrita do diário como dispositivo de pesquisa-formação e suas implicações com condições de trabalho e adoecimento docente. Busca-se ampliar questões sobre possibilidades do uso do método (auto)biográfico e seus desafios na contemporaneidade, especialmente, no que se refere ao fenômeno do adoecimento docente e a suas interfaces com o mundo do trabalho.

Compreendemos que professores e professoras acometidos(as) por doenças ocupacionais decorrentes ou intensificadas pelas inadequadas condições de trabalho, podem, mediante a escrita de si, refigurar suas vidas e o modo como vivem com a docência e como aprendem com o adoecimento. Trata-se de um estudo ancorado em princípios da pesquisa (auto)biográfica, utilizando o diário autobiográfico de cinco docentes, como dispositivo de pesquisa-formação, para acessar narrativas de processos de adoecimento laboral de professores da Educação Básica. A análise interpretativa-compreensiva configura-se como perspectiva de análise das narrativas dos docentes, construídas nos diários, suas experiências do adoecer e 
interfaces com condições objetivas e subjetivas do trabalho, inscritas num projeto de refiguração da vida-profissão, e de aprendizagens construídas com a doença.

Recorrer à grafia das memórias de processos de adoecimento configura-se como fértil para acessar repertórios de causas e efeitos da doença na vida e no exercício da profissão e, a partir disso, constituir modos de reexistência, apostando-se na reflexividade biográfica como suporte de conscientização e transformação de si.

A narrativa (auto)biográfica e as aprendizagens vinculadas às práticas de biografização inscrevem-se como dispositivos de empoderamento, na medida em que possibilitam aos sujeitos, quando narram suas experiências de vida sobre a doença, modos diversos de enfrentamento e de ressignificação das situações cotidiana da vida, da profissão e da doença. As palavras, expressas nas narrativas sobre as doenças permitem, através da arte do encontro consigo mesmo e com o outro, atitudes de escuta, de silêncios, de aprendizagens com o adoecimento (SOUZA, 2016; DELORY-MOMBERGER, 2016) e de representações sobre vidaformação-profissão como dimensões existenciais, marcadas pelas potências das palavras e das narrativas.

Com o propósito de avançarmos na compreensão sobre o adoecimento e sua relação com as condições de trabalho, consideramos importante destacar o papel de lutas coletivas que evidenciam historicamente uma consciência sobre a exploração do trabalhador. Para Araújo, Pinho e Massan (2019, p. 2), essa relação "é investigada desde os primeiros estudos que buscaram compreender os processos de adoecimento humano".

O movimento dos operários na luta por melhorias da relação saúde-trabalho, como descreve Dejours (2002, p. 18), implica compreender que “A organização dos trabalhadores traduziu-se na conquista primordial do direito de viver, [...]”. Ao sistematizar questões históricas sobre movimento operário e condições de trabalho, o autor destaca um período que vai da Primeira Guerra Mundial a 1968, no qual "é progressivamente o tema das condições de trabalho que se depreende das reivindicações operárias na frente pela saúde. A luta pela sobrevivência deu lugar à luta pela saúde do corpo" (p. 22). Enquanto a primeira "condenava a duração excessiva de trabalho", a segunda "conduzia à denúncia das condições de trabalho". (p. 25). Para Dejours (2002, p. 25, grifos nosso), "Por condição de trabalho é preciso entender, antes de tudo, ambiente físico [...], ambiente químico [...], o ambiente biológico (vírus, bactérias, parasitas, fungos), as condições de higiene, de segurança, e as características antropométricas do posto de trabalho.

São características antropométricas do trabalho docente aquelas que determinam a quantidade de alunos por turma, o uso do piloto - substituto do giz -, cadeira ergométrica, uso 
de tecnologias como computadores, datashow, dentre outros. Defendemos que a sala dos(as) professores(as) seja um ambiente adequado para descanso e estudo, além das condições salariais, contratuais e psíquicas.

É importante, em vista disto, frisar que “[...] a dimensão do risco está sempre presente, em maior ou menor grau, em qualquer atividade de trabalho, na medida em que a sociedade hodierna sofre coletivamente com essa problemática de forma diferenciada." (AMORIM JUNIOR, 2017, p 77).

Nessa linha discursiva, ao identificarmos riscos à saúde dos(as) professores(as) no exercício do trabalho docente, faz-se importante pensar em como, por meio dessas normas - de saúde, higiene e segurança -, é possível alcançar a redução dos riscos inerentes ao trabalho docente. “A proteção que o Direito oferece para a saúde do trabalhador há de atuar, não apenas sobre as condições de trabalho, mas, sobretudo, em face da organização do trabalho" (Ibid., p. 215).

Se por um lado, as organizações de trabalho precisam estar atentas às condições de trabalho dos trabalhadores pois "um ambiente de trabalho adverso pode causar problemas físicos e mentais, um consumo prejudicial de substâncias e álcool, absenteísmo e perda de produtividade" (OMS, 2017). Por outro, cabe aos trabalhadores ficarem atentos às estratégias criadas pela organização do trabalho.

No território do trabalho docente, o adoecimento ou o mal-estar é, muitas vezes, debitado unicamente na conta pessoal do(a) professor(a), não da organização e de suas condições de trabalho, deixando margem para interpretações do tipo "adoeceu porque é fraco" ou "está dizendo que está doente porque não quer trabalhar", o que não passa de uma visão ingênua, e talvez seja coerente afirmar que esse tipo de interpretação está mais para uma espécie de alienação político-cultural-social. Daí que é necessário conhecer mais e melhor o que está por trás das cortinas, o que está nos bastidores da docência e em seu cotidiano profissional.

Entretanto, a organização tem sido limitada pelas políticas públicas educacionais, especialmente no que se refere ao aspecto financeiro e modelos de gestão. Basta mirar no que acontece no chão das escolas para identificar inúmeros problemas, que vão desde à estrutura física à didático-pedagógica. Em grande medida, esses problemas são oriundos da falta de autonomia da gestão dos recursos financeiros por parte das secretarias de educação.

Assim, se por um lado, os textos da legislação e das políticas públicas alimentam o discurso dessa liberdade; por outro, as limita. O que temos observado é que o impacto na saúde docente é grande quando o sistema de ensino não consegue garantir uma organização e 
condições de trabalho necessárias para o exercício da profissão. É, portanto, imprescindível, que o município goze de assistência técnica e financeira para poder garanti-las.

Vale salientar que a discussão sobre condições de trabalho docente aparece sempre ancorando a de saúde docente. E para tratar de condições de trabalho docente tomamos como referências autores que discutem questões concernentes a profissão docente, especialmente Apple (2003), Marchesi e Martín (2003), Nóvoa (2007), Oliveira e Vieira (2012), Hypólito (2012), Barros, Heckert e Margoto (2008). Ao tratarem de mudanças em torno do trabalho docente na contemporaneidade, evidenciam o processo de (auto)intensificação do trabalho, autorresponsabilização, precarização, fragilidade da condição docente por exemplo. Nesses estudos, tem destaque a discussão sobre as condições de trabalho docente, que incluem as condições objetivas e as subjetivas. Para Hypólito (2012, p. 227), as “condições de trabalho têm sido negligenciadas a ponto de ter aumentado assustadoramente a precarização do trabalho docente", situação que apresenta como uma das principais consequências o adoecimento de professores(as).

No que se refere à saúde docente, compreendemos que as principais doenças que acometem o(a) professor(a) são relacionadas à problemas de voz, osteomusculares e mentais, tais como evidenciados por Araújo e Carvalho (2009) e Assunção e Oliveira (2009), as quais estão associadas às precárias condições de trabalho.

Para Dejours (2002, p. 25), a organização do trabalho designa "a divisão do trabalho, o conteúdo da tarefa (na medida em que ele dela deriva), o sistema hierárquico, as modalidades de comando, as relações de poder, as questões de responsabilidade.”. Para esse autor, o sofrimento mental "resulta da organização do trabalho" (Ibid., p. 25). Lutar por condições dignas de vida-trabalho não seria um dos componentes importantes do exercício da profissão? Estamos certos de que levar em consideração a relação entre trabalho e doença é um desafio e uma luta infindável, especialmente no momento que vivemos diante da crise sanitária e a intensificação do trabalho remoto por parte dos docentes.

O texto organiza-se em três seções que se articulam e buscam discutir aspectos concernentes ao trabalho de pesquisa-formação com narrativa docente, em seguida, problematiza questões relacionadas às escritas de si e do diário de pesquisa-formação como dispositivo de pesquisa e, por fim, sistematiza a perspectiva de análise interpretativacompreensiva das narrativas, situando dimensões entre imaginação e rigor no campo da pesquisa (auto)biográfica, notadamente das escritas de formação. 


\section{Por que trabalhar com narrativa docente?}

A pesquisa com narrativas (auto)biográficas ou de formação inscreve-se neste espaço onde o ator parte da experiência de si, questiona os sentidos de suas vivências e aprendizagens, suas trajetórias pessoais e suas incursões pelas instituições, no caso, especificamente a escola, [...]. (SOUZA, 2004, p. 410)

Acreditamos que quando uma pessoa passa a se conhecer, a refletir sobre sua história de vida, acessa um campo de possibilidades de mudança, cabendo a ela investir ou não nelas. O passado, com suas memórias, nos leva a identificar padrões, maneiras de lidar com os acontecimentos, a perceber como nos relacionamos conosco e com os outros. O presente é esse lugar de transição entre quem somos e quem podemos ser. $\mathrm{O}$ futuro enquanto horizonte de expectativas (RICOUER, 2012b) guarda essa semente do vir-a-ser.

É no sentido da "reconstrução" do passado e de criação de perspectivas de futuro que o projeto de refiguração da vida de professores(as) acometidos(as) por adoecimento se funda. E nele a escrita de si como sistemática da narrativa docente é assumida como uma ferramenta importante da historicidade da educação pois permite que o(a) docente "trabalhe sua vida". Contar sua história é um meio para transformá-la, pode traduzir-se como "um meio de brincar com o ritmo da vida, reconstruir o passado, apoiar o presente e embelezar o futuro." (GAULEJAC, 2018, s/p). Conhecer a história de professores(as), portanto, passa pelo conhecimento da história da educação em uma determinada sociedade.

O exercício da memória sobre os "espaços de experiência" efetua o elo entre tempo e narrativa. Esse exercício da memória nos leva à expansão da nossa própria biografia. Por meio dele acessamos lembranças de experiências de tempos longínquos ou daqueles bem recentes, fazemos "projeção de sensibilidades" e identificamos nossa "posição afetiva e afetante" no mundo. Ricouer nos conduz à reflexão de que:

[...] a atribuição da memória a alguém é uma operação muito complexa que pode ser legitimamente efectuada em benefício de todas as pessoas gramaticais: eu recordo-me, ele/ela recorda-se, nós, eles/elas, recordam-se. [...]. Vamos ver que este encadeamento é de tal ordem que, em certos casos de identidade colectiva, colocará de forma mais viva e mais inquietante o problema da sua justificação, ou seja, da sua purificação, ou cura, uma vez que é verdade que as nossas memórias colectivas são memórias feridas, doentes mais ainda do que as nossas memórias pessoais. Estando provisoriamente regulada esta questão da atribuição de igual direito de memória e, através da memória, de identidade a pessoas e comunidades, podemos confrontar-nos com a maior dificuldade, a da fragilidade da identidade. [...]. ${ }^{4}$

\footnotetext{
${ }^{4}$ Disponível em: https://www.uc.pt/fluc/uidief/textos_ricoeur/identidade_fragil.
} 
É preciso reconhecer, como afirma Ricouer, que "o trabalho da memória sobre si não se efectua sem um trabalho de dor, o qual não se resume à lamentação passiva [...]." memória não é somente rememoração pessoal e privada, mas igualmente comemoração, isto é, memória partilhada.".

Por meio de narrativas, acessamos memórias sobre outrem que por alguma razão contribuíram para sermos quem somos no presente. São memórias que estão associadas a diversas emoções e, por isso, nem sempre são simples de "dizer". Existe em todo enredo da história de uma vida a evidência contundente da coexistencialidade. Vamos assim nos conscientizando da necessidade do outro na constituição de nosso eu. A vida é uma realidade intersubjetiva, feita de interações constantes, em que parte destas escapam à narrativização.

Cada professor(a), ao narrar experiências da vida docente, vai marcando peculiaridades, tanto individuais como grupais. Essas narrativas informam disposições de gênero, raça, classe, cultura que vão delineando o perfil socioprofissional de um(a) docente. Disposições essas que mostram como a vida de uma pessoa está entrelaçada à vida de tantas outras, como a nossa história individual está vinculada à história coletiva. Por meio dessas histórias individuais, identificamos processos sociais. Podemos assim compreender “[...] processos de reprodução ou de ruptura com respeito ao seu meio de origem e os mecanismos de distribuição antroponômica (BERTAUX, 1977) e saber de que maneira o indivíduo está situado no espaço social.” (GAULEJAC, 2020, s/p).

Ao recordamos nossos "horizontes de expectativas", os quais são evidenciados na trama temporal entre passado, presente e futuro, alargamos a nossa consciência sobre quem somos e como agimos no mundo, mas também como queremos ser. No passado, criamos expectativas estas que dizem do que esperamos do futuro - que só no transcorrer do tempo saberemos sobre seu alcance real.

As narrativas docentes sobre processos de adoecimento laboral evidenciam o preço da espera por melhores condições de trabalho, seja a espera pela mudança de nível, pelo reconhecimento do trabalho que realizam, pelo interesse dos alunos com os estudos, por melhores recursos didático-pedagógicos, por melhorias infraestruturais da escola, entre outras. Esse preço, muitas vezes, se traduz em grande frustração e sofrimento.

Mas, há também as memórias agradáveis, aquelas de realização, de conquistas e alegrias. A espera por aquele resultado de um concurso que obteve aprovação, ou pelo aumento do salário que foi honrado após um longo investimento em formação, ou por aquele resultado

\footnotetext{
${ }^{5}$ Disponível em: https://www.uc.pt/fluc/uidief/textos_ricoeur/identidade_fragil.
} 
de um exame médico que te apavorara e que deu negativo. Até mesmo a simples espera por aquele prato preferido do qual o cheiro exala e te faz lembrar o sabor. Sim, "esperar" é verbo existencial, assim como o agir.

O fato é que, quando miramos as expectativas criadas em algum momento do passado, percebemos se elas se tornaram realidade ou não passaram de um projeto que se perdeu na passagem do tempo, fazemos um balanço da espera e frustração ou realização. Se a priori essas são noções que podemos denominar de "naturais", ampliando essa reflexão, encontramos o peso que os aspectos sociais, biológicos, psíquicos - considere o cultural e o econômico encerram sobre seu quantum. Então, o que fazer diante desse saber? Aceitar passivamente ou nos envolvermos no sentido de criar melhores condições para especialmente as novas gerações? Por que alguns vivem uma vida de espera permanente?

Segundo Pineau (2004, p. 38), a espera "[...] chega a ser uma quase-instituição de administração social" e é nesse sentido que faz uso da expressão "imposto de espera”. Temos assim um convite à reflexão sobre as marcas das desigualdades sociais sobre a passagem do tempo, sobre o modo como somos afetados por "uma temporalidade burocrática que aumenta a distância entre a necessidade ou o desejo e a satisfação.” (Ibid., p. 39).

Socialmente, quanto mais pobre for o contribuinte, mais pesado será esse imposto temporal de espera. Não são os ricos que povoam as filas e as salas de espera, mas os pobres, que assim perdem boa parte de seu tempo pessoal para ter acesso às assistências sociais: seu tempo tem um valor social tão pequeno que pode ser tomado quase à vontade. Volte amanhã. [...] (PINEAU, 2004, p. 39).

Essa noção de espera é potente no âmbito das pesquisas nas Ciências Humanas. Em Educação, ela nos é muito cara, tanto no sentido que podemos chamar de positivo como no seu oposto. A educação parece nos conduzir a ritmos diferentes entre a espera e o agir. O que marca essas diferenças em grande medida é o pertencimento social. São ritmos que se relacionam a lugares geográficos, à condição econômica, psíquica, biológica. Mudar de ritmo quase sempre exige um esforço muito alto. Muitos se frustram por não conquistar o esperado e concluem que o esforço e sofrimento relacionados não valeram a pena, o pior é que muitos se culpam por isso.

\section{Reflexividade biográfica}

A reflexividade autobiográfica, de acordo com Passeggi, Souza e Vicentini (2011, p. 372), refere-se à "capacidade de criatividade humana para reconstituir a consciência histórica das aprendizagens realizadas ao longo da vida.". Trata-se de um "voltar-se sobre si mesmo para 
tentar explicitar o que sente ou até mesmo perceber que fracassa nessa difícil tarefa de (re)elaboração da experiência vivida.” (PASSEGGI, 2016, p. 82).

Essas aprendizagens nos possibilitam, a partir do momento em que refletimos sobre o que nos aconteceu, tomar decisões que redefinem ou não esses horizontes de expectativas, considerando além do nosso "eu existencial", a existência do outro.

Ricouer reforça esse entendimento de que refletir sobre a vida é ampliar o campo de visão sobre si e o mundo, sobre os sentidos que nos tocam e movem, possibilitando, numa relação dialética, a estima a si mesmo e a solicitude. Para ele:

A reflexividade parece realmente carregar em seu bojo a ameaça de um retraimento, de um fechamento, ao arrepio da abertura para a amplidão, para o horizonte da "vida boa". Apesar desse perigo certo, minha tese é que a solicitude não se soma a partir de fora à estima a si mesmo, mas expande sua dimensão dialogal até aqui omitida. Por expandir, [...], entendo, sim, uma ruptura na vida e no discurso, mas uma ruptura que cria as condições para uma continuidade de segundo grau, de tal modo que a estima a si mesmo e a solicitude não possam ser vividas e pensadas uma sem a outra. (RICOUER, 2019, p. 199)

Considerou-se importante marcar a questão da solicitude porque o projeto de refiguração da vida-profissão está comprometido com a perspectiva da criação de disposições de cuidado de si, implicando-se "uma intensificação das relações sociais" (FOUCAULT, 2017, p. 69).

A reflexividade biográfica pode significar em si um movimento de transformação, nos situa no tempo, levando-nos a compreender quem somos e quem podemos ser. Transformação que é mais o resultado da compreensão dialética entre (inter)subjetividade e objetividade que um processo puramente subjetivo, como podemos verificar em Berteaux.

A transformação de si mesmo raramente resulta de um processo puramente subjetivo, e é fácil perceber como os 'movimentos da alma' mais íntimos, paixão, conversão religiosa ou decisão de suicídio, por exemplo, não podem ser compreendidos se não se considerar, pelo menos, o complexo de relações intersubjetivas que caracteriza o sujeito naquele momento. Quanto aos processos que transformam, pouco a pouco ou brutalmente, uma relação intersubjetiva forte, por exemplo, uma relação de casal, uma relação pai-filho ou uma relação de amizade, eles envolvem ao mesmo tempo as personalidades dos sujeitos e, frequentemente, a relação social objetivada que existe entre os lugares que ocupam. (BERTEAUX, 2010, p. 113).

A noção de reflexividade biográfica se associa à de identidade narrativa, cuja natureza "só se revela na dialética entre ipseidade e mesmidade" (RICOUER, 2019, p. 145 - Grifos nosso). A mesmidade indica o que é imutável do sujeito, trata-se do que o torna um ente social, da espécie humana; refere-se ao dizer do outro, como sobrenome, profissão, código genético, por exemplo. Já a identidade-ipseidade está na ordem do poder de autodesignação, indica o que caracteriza o sujeito como ser único, singular, trata-se de uma identidade móvel. Esta citação 
explicita bem como se dá a relação entre esses conceitos e a identidade narrativa e desta com a identidade pessoal:

[...] a ideia de identidade narrativa dá acesso a uma nova abordagem do conceito de ipseidade, que, sem a referência à identidade narrativa, é incapaz de desenvolver sua dialética específica, a da relação entre duas espécies de identidade, a identidade imutável do idem, do mesmo, e a identidade móvel do ipse, do si, considerada em sua condição histórica. [...]. (RICOUER, 2017, p. 116)

No campo da Educação, essa reflexividade, no exercício da memória sobre os espaçostempos de experiência, pode conduzir a uma redefinição não apenas de modos de ensinar, mas da escola como um todo. A formação vem sendo beneficiada por pesquisas que são desenvolvidas lançando mão de métodos (auto)biográficos. E é notório, especialmente no âmbito da pós-graduação, que a pesquisa (auto)biográfica tem sido bastante adotada nas últimas décadas no campo da formação de professores(as).

\section{Escritas de si e diário de pesquisa-formação: método e dispositivo de pesquisa}

[...] o trabalho com as narrativas parte das experiências individuais e coletivas, inscreve-se na temporalidade e reflexividade biográfica, possibilitando aos próprios sujeitos, quando narram suas experiências de vida e com o adoecimento construírem modos próprios de aprenderem com a cronicidade da doença, a superarem preconceitos, discriminação, estigmatização, através de processos implicados entre narrativas, refiguração identitária e modos próprios de viver com o adoecimento [...]. (SOUZA, 2018, p. 54).

Apreendemos que o uso do método (auto)biográfico, ao mesmo tempo que possibilitou apreender/analisar como os processos de adoecimento de professores(as) do Ensino Fundamental se relacionam com as condições de trabalho na rede pública municipal de ensino de Valença (BA), apresentou-se como suporte metodológico em um projeto que visa a refiguração da vida-profissão de professores(as) acometidos(as) por doenças ocupacionais. Dos métodos que aparecem no campo da pesquisa (auto)biográfica, optou-se pela "escrita de si".

Conforme Souza (2018, p. 44), é possível apreender, por meio de métodos (auto)biográficos, “[...] modos próprios de como os sujeitos narram suas experiências com a doença e como aprendem a viver com o adoecimento, implicando em formas de enfrentamento e de reconfiguração identitária, [...].”.

Segundo Helman (2009, p. 141), na perspectiva do tratamento médico, "todas as dimensões da doença do paciente poderão ser tratadas”, não apenas a física. Ele defende que "quando necessário, o tratamento pode ser compartilhado com um psicoterapeuta, conselheiro, padre, [...], ou até mesmo, em algumas situações, com um curandeiro sancionado" (Ibid., p. 
141). Para a autora, a escrita de si pode ser um dispositivo adotado nesse processo de tratamento.

Cabe ressalvar que a escrita de si no campo da pesquisa (auto)biográfica tem sido usada em diversas perspectivas metodológicas, a exemplo de memoriais, da documentação narrativa, do ateliê biográfico. São, portanto, muitas as possibilidades de "práticas autobiográficas".

Impõe-se, então, em toda a sequência autobiográfica (narrativas de vida, mas também, de certa forma, as múltiplas práticas autobiográficas comuns que objetivam inscrever a 'singularidade do eu' tal como diários, egomuseus, trocas epistolares, arquivos pessoais ${ }^{88}$ de toda natureza), a recordação de uma trajetória ou de uma história de vida que, ao menos parcialmente, justificaria o destino individual. [...] (CANDAU, 2019, p. 73-74).

Assumimos a pesquisa (auto)biográfica como método para a construção e socialização das narrativas relacionadas às condições de trabalho docente na contemporaneidade, a escrita de si se funda, primeiro, por se constituir uma importante forma de acessar dos(as) próprios(as) docentes o modo como percebem/interpretam essas condições em suas trajetórias de experiências profissionais; segundo, por propiciar a esses e essas professores(as) um exercício da memória que pode produzir uma maior compreensão e questionamentos sobre sua condição docente além da possibilidade da criação de disposições para a "transformação do cotidiano e do futuro". Ao discutir sobre efeitos e potências da escrita narrativa no campo da formação, Souza (2006) teoriza:

[...] a escrita da narrativa tem um efeito formador por si só. Isto porque coloca o ator num campo de reflexão, de tomada de consciência sobre sua existência, de sentidos estabelecidos à formação ao longo da vida, dos conhecimentos adquiridos e das análises e compreensões empreendidas sobre a sua vida, do ponto de vista psicológico, antropológico, sociológico e linguístico que a escrita de si e sobre si exige. Significa entender que a narrativa escrita objetiva trabalhar com o conhecimento experiencial ao longo da vida e as possibilidades formativas construídas nas experiências vividas. (2006, p. 60)

Esse pensamento encontra ressonância em Rago (2018, p. 57) quando afirma que "escrever-se" é "um modo de transformar o vivido em experiência, marcando sua própria temporalidade e afirmando sua diferença na atualidade". E também com o que diz Pineau (2004, p. 157) sobre o movimento de autoformação, tratando de uma autonomização do protagonista: "Esta autonomização provoca um movimento de personalização, de individualização, de subjetivação da formação.”.

Numa leitura foucaultiana, pode-se afirmar que a escrita de si "é entendida como um cuidado de si e também como abertura para o outro, como trabalho sobre o próprio eu num contexto relacional, tendo em vista reconstituir uma ética do eu.” (RAGO, 2018, p. 50). 
Essa escrita pode possibilitar a professores e professoras, acometidos(as) por adoecimento laboral, maior conhecimento sobre causas e consequências, bem como contribuir com seu tratamento, mediante novas conexões com o seu corpo (JOSSO, 2010a), os sintomas, preconceitos, medos, formas de resistências e disposições relacionadas à refiguração narrativa da identidade. "Isto porque, o ato de lembrar e narrar possibilita ao ator reconstruir experiências, refletir sobre dispositivos formativos e criar espaço para uma compreensão da sua própria prática.” (SOUZA; CORDEIRO, 2007, p. 3).

E dentre as diversas práticas narrativas, optou-se pelo diário como dispositivo metodológico. Existem, segundo Hess (2006), seis formas particulares do diário: 1. diário íntimo ou pessoal, feito pelo adolescente ou pelo homem de letras; 2. diário de viagem, assim como o diário de bordo, se limita ao período de uma ou mais viagens; 3. diário filosófico, tratase de uma redação em torno de temas que se pode retomar; 4. diário de pesquisa, no qual o pesquisador registra suas hipóteses e seus achados, a propósito de um objeto que é previamente dado, em um campo específico e ao longo de seu aparecimento; 5. diário de formação - diário institucional; 6. diário dos momentos.

Outras nomenclaturas, mais gerais, são: diários biográficos e diários autobiográficos. "A escrita de diários biográficos constitui em "escrita sobre a vida" (bios=vida, grafia=escrita), tentando compreender e articular as experiências de uma outra pessoa. A escrita de diários autobiográficos envolve o processo de contar a história da sua própria vida" (HOLLY, 2007, p. 101). Enquanto o diário autobiográfico se refere à escrita de si sobre a vida, o diário biográfico trata da escrita sobre a vida do outro. O elemento comum, portanto, entre ambos é a escrita da vida, esta que acontece no mundo, lugar onde o eu e o outro coexistem.

Conforme afirma Lejeune (2014), um diário se vincula às seguintes utilidades: conservar a memória, sobreviver, desabafar, conhecer-se, deliberar, resistir, pensar, escrever. $\mathrm{O}$ autor diferencia "quatro funções do diário, sem esquecer que pode haver outras e que um diário real preenche várias funções ao mesmo tempo. Trata-se da expressão, da reflexão, da memória e do prazer de escrever" (LEJEUNE, 2014, p. 318). Defende que o diário é uma autobiografia interminável: "É enquanto diário que a autobiografia é interminável - da mesma maneira, é enquanto autobiografia que o diário pode ser terminado” (Ibid., p. 315).

Para Clandinin e Connelly (2015, p. 145), os diários "são um meio poderoso para que as pessoas possam dar relatos de suas experiências". No diário, ao escrevermos sobre o que nos aconteceu hoje, geralmente recorremos ao passado, para em seguida criar expectativas. Por que estou passando por isso? O que fiz para chegar aqui? Como me tornei o que sou hoje? O que posso mudar para alcançar o que entendo que me fará melhor? Essas questões emergem nos 
fazendo refletir sobre a nossa história. O presente escrito nos leva, por meio da reflexividade a colocar em cena a dinâmica entre passados e futuros de uma existência. Se por um lado, questiono o que me fez ser quem sou, por outro também me questiono sobre possibilidades de mudanças. O que é possível mudar? O que se manterá independente do meu desejo e esforço?

Esse investimento reflexivo sobre o passado nos faz lembrar que lá nesse tempo criamos projetos para o futuro - esses que agora fazem parte do passado -, e gera, a partir disso, decisões que atuam sobre nosso horizonte de expectativa. Podemos depreender de tal compreensão que:

[...] a escrita de um diário representa uma nova voz de aproximação e um território para as subjetividades, representa um espaço que tem funções terapêuticas, além de éticas e estéticas. Graças a escrita íntima, o autor se explica e se constrói a si mesmo, confronta-se com seus projetos de vida, suas escolhas, suas prioridades que são fixadas por ele mesmo ou que se impõem pela educação. (CUNHA, 2007, p. 50)

O tipo de diário usado como dispositivo de pesquisa foi o autobiográfico. Sousa (2021) apresenta duas versões do diário no desenvolvimento da pesquisa: 1. a que foi elaborada pelos cinco professores-colaboradores da pesquisa, denominando-a de "diário de pesquisaformação"; 2. a outra versão, a qual identificou como diário autobiográfico, escrita exclusivamente pela pesquisadora, foi usada na vivência do projeto de refiguração da vidaprofissão, como espaços de experiência e (trans)formação.

O diário de pesquisa-formação foi assumido como um lugar de expressão de modos de significação das experiências de professores(as), através do qual buscou-se ampliar o debate sobre a relação entre processos de adoecimento e condições de trabalho docente para a elaboração de projeto de refiguração da vida, fundado num "projeto reflexivo do eu” atrelado à defesa do exercício do cuidado de si.

\section{Projeto de refiguração da vida-profissão}

A noção de refiguração é empregada no sentido da redefinição da realidade histórica, mediante "reformulação da referência". Esse uso é devido a própria aposta na narrativa autobiográfica. Afinal, “as (auto)biografias são constituídas por narrativas ${ }^{6}$ em que se desvelam trajetórias de vida. Esse processo de construção tem na narrativa a qualidade de possibilitar a autocompreensão, o conhecimento de si, àquele que narra sua trajetória" (ABRAHÃO, 2004, p. 203).

\footnotetext{
6 "Através da narrativa, as pessoas lembram o que aconteceu, colocam a experiência em uma sequência, encontram possíveis implicações para isso, e jogam com a cadeia dos acontecimentos que constroem a vida individual e social" (JOVCHELOVICH e BAUER, 2015, p. 91).
} 
Segundo Ricouer (2012b, p. 421), "a temporalidade entra na linguagem na medida em que esta configura e refigura a experiência temporal." Ele estabelece como fio condutor da "mediação entre tempo e narrativa" a articulação entre os três momentos da mímesis que, numa "brincadeira séria" - segundo o próprio autor -, denominou como: mímesis I (prefiguração), mímesis II (configuração) e mímesis III (refiguração), tendo a mímesis II a função de mediação entre a I e III.

Ao narrar, o sujeito integra eventos isolados numa totalidade inteligível e faz a síntese do heterogêneo, entre concordâncias e discordâncias. A configuração narrativa (mimese II) refigura (mimese III) a experiência pré-figurada (mimese I). A mimese II faz a mediação entre um antes do texto (campo prático) e o depois do texto (recepção da obra). (OLINDA, PINTO, 2019, p. 270).

A prefiguração, modo mimético I, remete "à semântica do desejo, que por enquanto só comporta os traços pré-narrativos vinculados à demanda constitutiva do desejo humano." (RICOUER, 2012b, p. 421).

Mímesis I: imitar ou representar a ação é, em primeiro lugar, pré-compreender o que é o agir humano: sua semântica, sua simbólica, sua temporalidade. É nessa pré-compreensão, comum ao poeta e a seu leitor, que se delineia a construção da intriga, com ela a mimética textual e literária. (RICOUER, 2012a, p. 112)

Essa mimética textual e literária não está, portanto, fechada sobre si própria, dado que se refere à ação dos sujeitos. Ricouer esclarece que mímesis "não é uma simples imitação, no sentido de uma cópia, de uma réplica, de uma duplicação, mas é uma reorganização a um nível mais elevado de significação e de eficiência." .

A Mímesis II refere-se à "dimensão configurante propriamente dita, graças à qual a intriga transforma os acontecimentos em história." (2012a, p. 115). "O modo configurante tem como característica própria colocar os elementos em um complexo único e concreto de relações. É o tipo de compreensão que caracteriza a operação narrativa.” (2012a, p. 263)

Enquanto ato configurante, mímesis II "consiste em tomar juntamente as ações particulares ou o que chamamos os incidentes da história; dessa diversidade de acontecimentos, ele tira a unidade de uma totalidade temporal." (RICOUER, 2012b, p. 116). Consiste na construção de "uma intriga, [...] uma síntese do heterogéneo, uma vez que a organização dos factos numa história contada transforma uma multiplicidade desordenada de acontecimentos numa narrativa unificada" 8 . É esse ato "que extrai uma figura de uma sucessão, revela-se para

\footnotetext{
${ }^{7}$ Disponível em: https://www.uc.pt/fluc/uidief/textos_ricoeur/autocomprehensio_et_histoire.

${ }^{8}$ Disponível em: https://www.uc.pt/fluc/uidief/textos_ricoeur/autocomprehensio_et_histoire.
} 
o ouvinte ou o leitor na capacidade que a história tem de ser acompanhada" (RICOUER, 2012b, p. 116).

Nesse sentido, a questão é "[...] o processo concreto pelo qual a configuração textual faz mediação entre a prefiguração do campo prático e sua refiguração pela recepção da obra.” (RICOUER, 2012a, p. 95). O autor explica que acompanhar uma história "é avançar em meio a contingências e peripécias sob a condução de uma expectativa que encontra sua satisfação na conclusão", relacionando-a à capacidade de entender a história, que, segundo ele, tratar-se-ia de "entender como e por que os sucessivos episódios conduziram a essa conclusão, que, longe de ser previsível, deve ser finalmente aceitável, como sendo congruente com os episódios reunidos." (RICOUER, 2012a, p. 116-117).

E mímesis III "se define pela identidade narrativa de um indivíduo ou de um povo, decorrente da retificação sem fim de uma narrativa anterior por uma posterior, e da cadeia de refigurações que disso resulta." (RICOUER, 2012b, p. 42, grifo nosso). Segundo ele, “a identidade narrativa é a resolução poética do círculo hermenêutico" (Ibid., p. 421).

Ricouer nos leva a entender que o que acontece nesse círculo se trata mais de uma espiral do que de um círculo propriamente dito, destacando que é incontestável o entendimento de que "a análise é circular". O que refuta é a ideia de se tratar de um "círculo vicioso". Nesse sentido, ele afirma: “[...] preferiria falar de uma espiral sem fim que faz a meditação passar várias vezes pelo mesmo ponto, mas numa atitude diferente" (Ibid., p. 421).

Essa referência da espiral, a nosso ver, nos possibilita entender melhor a ideia de "cadeia de refigurações", pois, como ele mesmo diz, “a vida não cessa de ser refigurada". Cabe ressaltar que a transição entre mímesis II para a III, é “operada pelo ato de leitura” (2012a, p. 130).

Para Ricouer (2012b, p. 419), “[...] a história de uma vida não cessa de ser refigurada por todas as histórias verídicas ou fictícias que um sujeito conta sobre si mesmo. Essa refiguração faz da própria vida um tecido de histórias narradas.”. As histórias narradas nos fazem compreender quem somos e por que somos de um certo modo e não de outro. Através delas, (re)construímos a nossa identidade narrativa, esta que não é acabada, que faz a vida bailar até outras pistas.

No campo da Educação, essa teoria tem sido apropriada por autores da pesquisa (auto)biográfica, cabendo destacar os estudos de Pineau (2004), Delory-Momberger (2012) e Passeggi (2008), no que se refere ao desenvolvimento de projetos de pesquisa-formação.

Passeggi (2008) apresenta uma articulação entre a tripla mímese (RICOEUR, 2012) e as figuras antropológicas (JOSSO, 2010b). Ela sintetiza o trabalho biográfico no projeto de formação em três etapas: 
1. Na dimensão iniciática (prefiguração), encontramos a arte da rememoração - que fatos marcaram minha vida? -, momento em que os(as) partícipes são identificados(as), respectivamente, formador(a) e professor(a) ou narrador(a) em formação com as figuras do Ancião e do Herói nessa busca dos fatos significativos que marcaram o percurso da vida, contribuindo para compreender a formação;

2. Na dimensão maiêutica (configuração), entramos na arte da reflexão e da construção da história: o que esses fatos fizeram comigo? Encontramos o Animador (formador/a) e o Artista (professor/a - narrador/a em formação), que reinventam a tradição, questionando valores, desconstruindo e construindo conhecimento;

3. Na dimensão hermenêutica (refiguração), estamos diante da arte da interpretação: o que faço agora com o que isso me fez? Nessa etapa, encontram-se a figura antropológica do Balseiro (formador/a), que se retira da cena, e o Intérprete (professor/a - narrador/a), que assume o papel do primeiro na vida e na profissão. (PASSEGGI, 2008, p. 55).

Outra síntese que a referida autora faz é a do processo de mediação biográfica, configurando-se como "o trabalho sobre a vida e o eu em três níveis: o da evocação sobre a formação, o da reflexão que produz conhecimento e o da interpretação que permite tirar 'as lições da vida' e gerar aprendizagens" (PASSEGGI, 2008, p. 55). Ainda sobre o modo da mímesis III, a autora afirma que se trata do momento "[...] da refiguração do mundo criado pelo texto, o que permite a quem narra ter acesso a um novo tempo de teorização ou sistematização da própria experiência de pesquisa-formação: o da produção do conhecimento incorporado, na e pela escrita”. (PASSEGGI, 2016, p. 81)

A discussão proposta por Pineau (2004, p. 210) sintetiza a tríplice mímesis do seguinte modo: a vida é "configurada pela narrativa e pela reflexão", sendo antes "prefigurada por uma certa vivência e, em seguida, refigurada pelos efeitos da operação sociolinguística”.

A noção de performatividade biográfica, conforme discutida por Delory-Momberger, (2012) colabora com essa perspectiva que Pineau apresenta. Sobre essa questão, a autora afirma que:

A noção de performatividade ganha aqui todo o seu sentido: é na enunciação de si, na fala de si mesmo e de sua existência que o narrador pode encontrar o meio de 'reunir' sua experiência de um espaço fracionado e em perpétua mudança e dar a essa experiência a continuidade que esse espaço não the oferece mais [...]. (DELORY-MOMBERGER, 2012, p. 90).

A referida autora, ao tratar da relação entre o eu e o outro, quando se refere à performatividade biográfica, chama a atenção para o seguinte:

Longe de remeter a uma interioridade inatingível, a fala de si, a que o indivíduo dirige a si mesmo e a que ele dirige ao outro, tem como resultado a conciliação do espaço-tempo individual com o espaço-tempo social. Ela implicita um saber prático dos mundos sociais, das modalidades da ação, dos 
discursos públicos; ela tece um enredo com uma racionalidade e uma operatividade sociais às quais os indivíduos estão entrelaçados. (DELORYMOMBERGER, 2012, p. 96).

Essa ideia do entrelaçamento dos indivíduos, no sentido de demarcar a questão da alteridade num projeto que se funda no dizer de si, merece destaque. Existiria $u m$ si sem $u m$ outro? Ao narrar sobre a relação entre processos de adoecimento e condições de trabalho, sobressaltou aí a influência do outro (colega, superior hierárquico, aluno(a) etc.). O outro como referência fundante do si-mesmo. E o reconhecimento de que um si-mesmo é, ao mesmo tempo, um outro do outro, logo, sua referência. A percepção dessa dialética entre o si-mesmo e o outro (RICUOER, 2019) pode nos levar a atitudes de maior alteridade, éticas no mundo, contrariando os ditames do individualismo. "Pode-se dizer, assim, que o si-mesmo é refigurado pela aplicação reflexiva das configurações narrativas. Desse modo, [...] a identidade narrativa, constitutiva da ipseidade, pode incluir a mudança, a mutabilidade, na coesão de uma vida". (RICOUER, 2012b, p. 419)

A refiguração é, grosso modo, uma dinâmica de transformação. Antes da configuração, o que existe é um conjunto de memórias que guardam experiências de modo espaçado. Tratase de um processo que se constitui a partir de um exercício sobre si, de conhecimento de si no sentido de um re-figurar, figurar de novo. Uma nova figura que se funda na identidade narrativa, no modo como o sujeito se vê, se diz e se projeta no mundo.

Parte-se, portanto, do pressuposto de que a "[...] refiguração pela narrativa confirma este traço do conhecimento de si próprio [...]"9 (RICOEUR, 1991, p. 80). E tem como objetivo uma ampliação da consciência de si, mediante reflexividade autobiográfica, esta que se traduz como condução do sujeito à reflexão de si num movimento de busca por uma vida, pessoal e profissional, mais digna.

Sob a perspectiva da assunção da transformação, a partir da transmissão de experiências do adoecer e da "dialética entre o si-mesmo e o outro", é que se elabora um projeto de refiguração da vida-profissão pela abordagem (auto)biográfica. E refigurar a vida-profissão, movimento inconclusivo por ser da ordem do continuum, tem a ver com a experiência do reconhecimento mútuo (RICOUER, 2017) e os sentidos mobilizados pelos cruzamentos das histórias, narrativas e escritas com as professoras e o professor. No movimento de análise, destacam-se suas importantes contribuições - ao exporem causas e consequências dos processos de adoecimento - que apontaram caminhos para experiências de saúde física, psíquica e social, numa vertente colaborativa e partilhada de experiências do adoecer

\footnotetext{
9 “[...] refiguration by narrative confirms this aspecto self-knowledge” (RICOEUR, 1991, p. 80, tradução nossa).
} 
relacionadas às suas condições de trabalho docente. De tal modo, que é necessário considerar que:

Toda experiência possui um contorno que a delimita e a distingue e, ao mesmo tempo, se delineia sobre um horizonte de potencialidades que constituem seu horizonte interno e externo: interno no sentido de que é sempre possível detalhar e precisar a coisa considerada no interior de um contorno estável; externo no sentido de que a coisa visada mantém relações potenciais com qualquer outra coisa no horizonte de um mundo total, que nunca figura como objeto de discurso. [...]. Porque estamos no mundo e somos afetados por situações tentamos nos orientar nele pela compreensão e temos algo a dizer, uma experiência para trazer para a linguagem e para compartilhar. (2012a, p. 133)

Em suma, trata-se de um projeto que, parafraseando Passeggi (2008), se nutre da evocação sobre a relação entre processos de adoecimento e condições de trabalho docente, o da reflexão que produz conhecimento acerca dessa relação e o da interpretação que permite tirar "as lições da vida" dessas experiências do adoecer e gerar aprendizagens. Nele, há uma ênfase marcante em torno de uma necessária reivindicação por condições de trabalho adequadas.

\section{Tempos do movimento de refiguração}

Metodologicamente, este projeto segue os modos miméticos: mímese I - tempo de prefiguração, mímese 2 - tempo de configuração e mímese 3 - tempo de refiguração, e está estruturado da seguinte forma:

Tempo de prefiguração, trata-se da primeira operação mimética que traduz uma precompreensão do mundo, com a identificação de acontecimentos por seus traços estruturais, simbólicos e temporais. Aqueles que aparecem como os mais significativos no legado da experiência.

Nesse tempo, os diários são designados como referência primordial, pois apresentam, mediante os textos autobiográficos, registros da interpretação de experiências do adoecer que se vincula a histórias anteriores, às vezes, a traumas que ficaram imantados, que parecem se atualizar como a forma de "um convite inconsciente" numa repetição que pode ser ilustrada como um círculo vicioso.

Desse modo, o diário autobiográfico trata de um suporte para esse exercício de identificação de episódios mais significativos que marcaram a vida - pessoal e profissional -, considerando a relação entre processos de adoecimento e as condições de vida-trabalho.

Tempo de configuração, operação que extrai dos acontecimentos sua inteligibilidade mediante o poder de mediação. Designa uma construção de uma intriga, a qual se torna a 
mediadora entre esses acontecimentos e uma história. Uma tessitura que conjuga intenções, causas e acasos; ela extrai uma configuração temporal de uma sucessão de acontecimentos discretos pela síntese do heterogêneo.

Essa operação coloca esses acontecimentos em "um complexo único e concreto de relações. É o tipo de compreensão que caracteriza a operação narrativa." (RICOUER, 2012a, p. 263). Por meio dela, elabora-se um tecido das histórias narradas. A reunião dos episódios se dá mediante a interpretação que se faz deles, de compreender o que eles fizeram da vida. Temse a oportunidade de avaliar valores e atitudes que se fazem presentes tanto na dimensão pessoal quanto na profissional. É uma elaboração que nos possibilita refletir sobre os espaços de experiências no âmbito das fases da vida - intrauterina, infância, adolescência e adulta -, localizando nesta última a trajetória profissional. Configurar, portanto, implica tecer relações, construindo assim uma história.

Tempo de refiguração, operação que marca a interseção entre o mundo do texto e o mundo do leitor. É, portanto, o tempo do leitor, o momento de leitura que faz a unidade do percurso de mímesis I à mímesis III, mediante mímesis II, assegurando "a transição entre configuração na narrativa e a nova figuração do mundo na práxis" ${ }^{10}$, o que se traduz como círculo hermenêutico. A configuração é um modo de reunião de vestígios de nosso passado, à medida que o nosso presente o interroga, o que nos possibilita acessar recordações dolorosas, das quais fomos protegidos por mecanismos de defesa e assumir outras políticas de vida.

Essa percepção de si como parte de uma teia de interações, num investimento da transformação de si - e também do social -, ancora-se no seguinte entendimento: porque existirão novos episódios significativos, a vida nos possibilita elaborar uma nova figuração a partir da reunião deles, que se faz pelo exercício reflexivo, o qual permite a tomada de decisões sobre o que fazer a partir do que aconteceu.

Sendo assim, o círculo hermenêutico, ao se fechar, se abre para um novo movimento de refiguração. O que se pretende nesse tempo é um movimento de "políticas de vida" que se inscrevam como modos de reexistir no território do trabalho docente e na vida.

O círculo hermenêutico entre o tempo e a narrativa docente pode ser assim ilustrado:

\footnotetext{
${ }^{10}$ Disponível em: https://www.uc.pt/fluc/uidief/textos_ricoeur/autocomprehensio_et_histoire.
} 
Figura 1 - Círculo hermenêutico

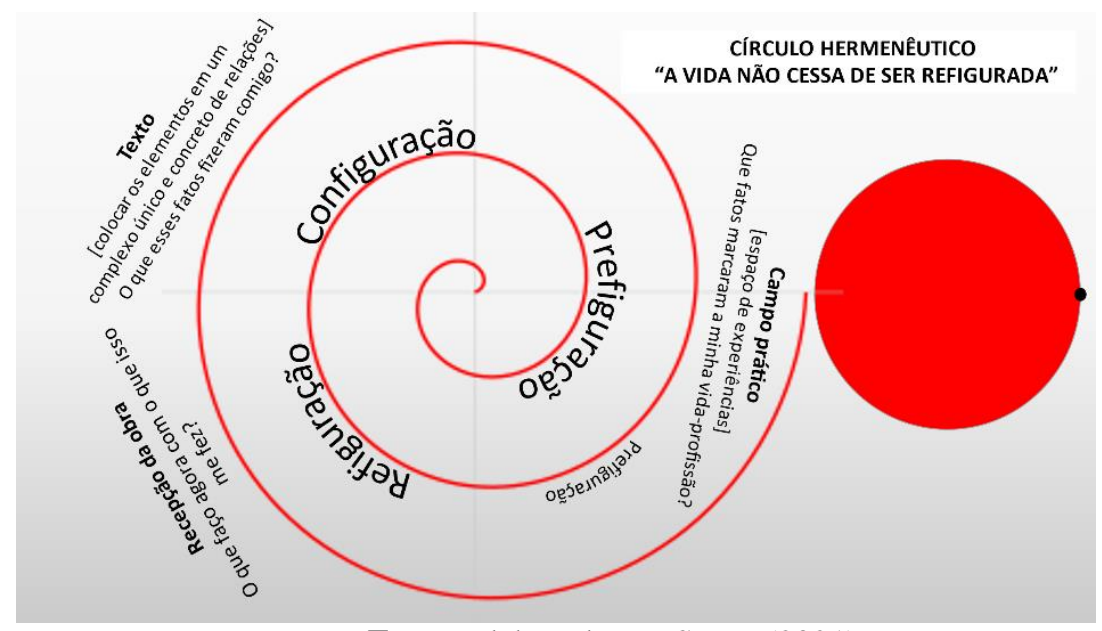

Fonte: elaborado por Sousa (2021).

Na imagem da espiral, vislumbramos o caminho realizado da mímese I à mímese III pela mediação da mímese II. Um caminho, como disse Ricouer, que faz a reflexão passar muitas vezes por um mesmo ponto, mas numa atitude diferente.

O círculo vermelho representa a análise, pois como vimos anteriormente, trata-se de entender que a análise é sempre circular. Ela, diferente da espiral, se fecha. Nesse percurso, identificam-se as noções de espaço de experiências e horizontes de expectativas. O primeiro como expressão do passado e o segundo do futuro. O presente está entre eles, é nesse tempo que se vivencia a tríplice mímeses como mediação entre tempo e narrativa.

Desse modo, o círculo hermenêutico situa a relação da narrativa com as três dimensões da temporalidade: 1. o trabalho sobre o passado com o fim de restaurar, reparar, relacionar acontecimentos; 2. o trabalho sobre o presente, sobre a história "incorporada", ou seja, sobre a maneira como age sobre si mesmo no presente; embora não possamos mudar o passado, podemos modificar nossa relação com ele, entendendo até que ponto e de que maneira essa história segue estando presente em nós mesmos; 3. o trabalho sobre o futuro, dessa capacidade dos homens para situar-se com respeito a seu passado depende sua capacidade de projetar-se num futuro (GAULEJAC, 2018).

\section{Análise interpretativa-compreensiva de narrativas: entre imaginação e rigor}

[...] Destacaremos apenas um princípio fundamental: as significações de um texto se situam no encontro de dois 'horizontes', o do sujeito e o do analista. O que está além do horizonte do analista não pode ser percebido por ele. $[\ldots]$ 
Imaginação e rigor, essa é a dupla fecunda que produz uma boa análise compreensiva. [...]. (BERTEAUX, 2010, p. 107).

Trabalhar com métodos (auto)biográficos exige do pesquisador o conhecimento de dispositivos de construção de narrativas e métodos de análise que possibilitem diálogos cruzados e implicados com as histórias e significados narrados.

Para realizar a análise das narrativas, partimos da compreensão de que "as relações entre história de vida, desenvolvimento pessoal e profissional, saberes da docência e caracterização do trabalho docente, reafirmam a necessidade de atentarmos para uma escuta sensível da voz dos professores.” (SOUZA, 2006, p. 45). A perspectiva de análise interpretativa-compreensiva, segundo Sousa (2021), foi a chave para um olhar e essa "escuta sensível” do que fora narrado pelo professor-colaborador e pelas professoras-colaboradoras.

O uso da análise interpretativa-compreensiva, portanto, se deu mediante entendimento da "implicação e importância que tem a narrativa em contexto de pesquisa, a partir da fenomenologia das experiências." (SOUZA, 2014, p. 43). Observou-se, na dinâmica da análise das narrativas sobre a relação entre processos de adoecimento e condições de trabalho, a elucidação de um quadro que tinha em relevo aspectos subjetivos, intersubjetivos e objetivos. Cabe ao sujeito que analisa sua própria história compreender esse quadro e refletir sobre ele, para assim vislumbrar um projeto de si.

Nessa análise interpretativa-compreensiva das narrativas, utilizou-se a ideia “[...] metafórica de uma leitura em três tempos: Tempo I: pré-análise/leitura cruzada; Tempo II: leitura temática - unidades de análise descritiva; Tempo III: leitura interpretativa-compreensiva do corpus [...]." (SOUZA, 2014, p. 43).

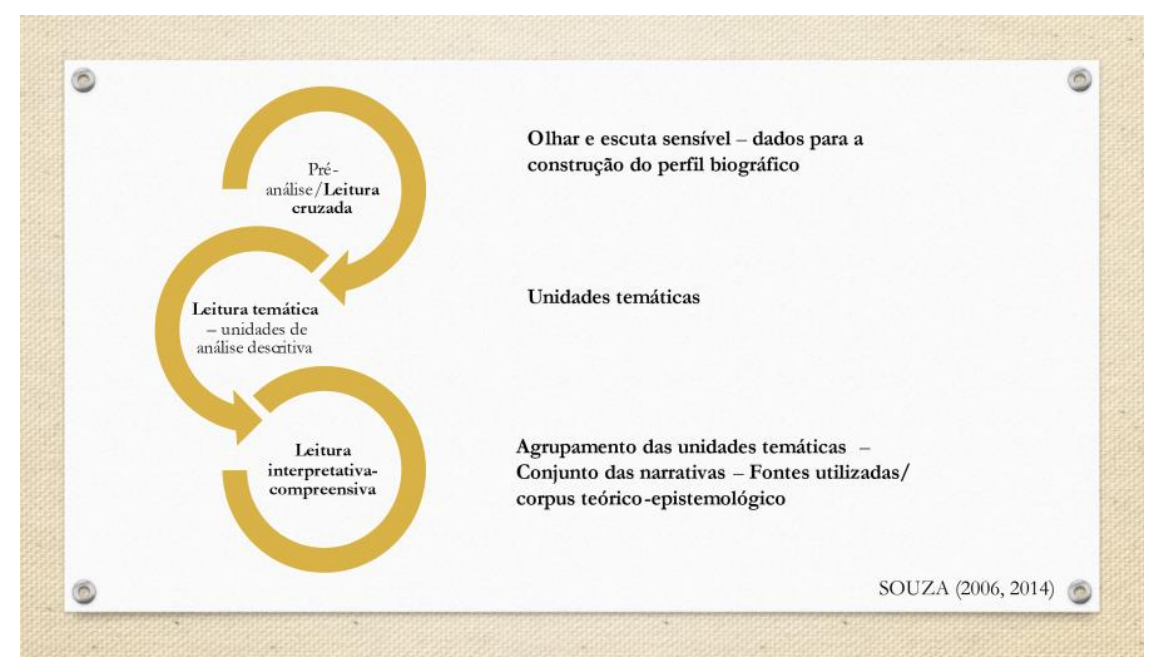

Figura 2 - Tempos de análise

Fonte: elaborada por Sousa (2021). 
O Teтро I, denominado como tempo da "pré-análise/leitura cruzada", se dá mediante compreensão de que a análise já inicia na escuta, na transcrição, o que se aplica na digitação dos diários, visto que,

[...] centra-se na organização e leitura das narrativas, tendo em vista a construção do perfil do grupo pesquisado, para, em seguida avançar na leitura cruzada, a fim de apreender marcas singulares, regularidades e irregularidades do conjunto das histórias de vida-formação. (SOUZA, 2014, p. 46).

Nesse tempo de pré-análise/leitura cruzada, foi realizada a digitação dos diários, o que possibilitou conhecer modos de narrar dos(as) professores(as) colaboradores(as) e destacar marcas singulares, regularidades e irregularidades, as quais são abordadas nos capítulos de análise dessas narrativas. Nesse tempo, foi feito um perfil biográfico dos sujeitos da pesquisa professoras ${ }^{11} \mathrm{SP}, \mathrm{SC}, \mathrm{VP}$ e RS e do professor BS.

Depois, portanto, de apreender essas marcas nas narrativas docentes, realizou-se uma análise cruzada, identificando no conjunto dos diários os aspectos informados sobre a relação entre processos de doença e condições de trabalho. Pelo que se depreende desses diários, constatou-se que há muita angústia, estresse, sofrimento e patologias físicas que se produzem pelas insuficientes condições de trabalho docente. E, logo em seguida, transitou-se para o Tempo II, o qual possibilitou eleger as unidades de análise temática.

As unidades de análise descritiva - ou unidades temáticas - emergiram através de características comuns identificadas nos diários, a saber: 1 . origem social; 2. gênero; 3 . entrada na profissão docente; 4. cotidiano docente; 5. experiências do adoecer; 6. necessidade de reconhecimento; e 7. estratégias de defesa. Com as unidades temáticas definidas, a análise se potencializa, permitindo diálogos com o corpus empírico-teórico da pesquisa.

O Tempo III, considerado como momento da análise interpretativa-compreensiva (SOUZA, 2006), configura-se como momento fundante - síntese do trabalho - em que se gera potência no trabalho, visto que:

O Tempo III - análise interpretativa-compreensiva - vincula-se ao processo de análise, desde o seu início, visto que exige leituras e releituras individuais e em seu conjunto do corpus das narrativas, recorrendo aos agrupamentos das unidades de análise temática e/ou ao conjunto das narrativas e das fontes utilizadas. (SOUZA, 2014, p. 46).

Trata-se de um tempo em que a compreensão se alarga sobre o dito e até mesmo sobre o não dito - o que está nas entrelinhas -, mediante o ato de explicação que se constitui pelas vias da interpretação. Nesse sentido, podemos dizer que “[...] a compreensão precede,

\footnotetext{
${ }^{11}$ As siglas correspondem as letras do nome e sobrenome dos colaboradores da pesquisa.
} 
acompanha e envolve a explicação, esta, por seu turno, desenvolve analiticamente a compreensão." $" 12$.

Nesse tempo, o cruzamento das unidades de análise descritiva com o campo teórico permitiu um aprofundamento sobre a relação entre processos de adoecimento e as condições de trabalho dos(as) professores(as) da rede pública municipal de ensino de Valença (BA).

Destacamos que no processo de análise das narrativas buscou-se não fazer julgamento de valor, apontando erros ou acertos, e que a presença dos(as) teóricos(as)/autores(as) se justifica pelo simples fato deles terem algo a dizer sobre o dito desses(as) professores(as)colaboradores(as), com o estabelecimento de diálogos sobre o objeto de estudo.

As unidades temáticas são analisadas e implicadas com a constituição do terceiro tempo da análise, em diálogo com o corpus teórico-epistemológico, com a exposição de excertos narrativos que elucidam tanto determinantes específicos quanto os mais gerais de processos de adoecimento decorrentes de inadequadas condições de trabalho. Esse corpus teóricoepistemológico foi se constituindo no movimento da análise a partir do que narram os cinco sujeitos da pesquisa.

A análise interpretativa-compreensiva, ao contemplar o modo como cada professor(a) desenvolve sua narrativa, desvelando experiências no território do trabalho docente, com destaque para seus processos de adoecimento, possibilita identificar especificidades de quadros clínicos explicitados e como cada um(a) vai significando a vida-profissão e sua permanência como trabalhador(a) docente, bem como seus processos de aprendizagens com a doença. Constata-se que na prática de escrita de si, constitutiva do diário, é impossível se narrar sem a referência ao "outro", na medida em que nas narrativas emergem referência ao coletivo docente e a outros(as) atores(as) das cenas escolares. Os modos como os docentes narram expressam uma singularidade, explicitando sentidos, significados, imagens e representações de si, bem, como modos que nos fazem reconhecer o que é uno e o que é plural nessas histórias, o que é da dinâmica pessoal e o que é da institucional na interface entre vida-profissão e saúde-doençaprofissão no mundo cotidiano da docência da Educação Básica.

\footnotetext{
${ }^{12}$ Disponível em: https://www.uc.pt/fluc/uidief/textos_ricoeur/autocomprehensio_et_histoire?web=1\&wdLOR=cE2C0DAAA925B-495E-9D63-F1B84E6346A1.
} 


\section{Considerações finais}

A pesquisa evidencia que a relação entre processos de adoecimento e condições laborais necessita, cada vez mais, de uma ampla atenção na contemporaneidade. Existe uma tendência à precarização das condições de trabalho docente, o que amplia/agrava o quadro de adoecimento e sofrimento. Esse fenômeno de precarização tem sido mais visível a partir da Reforma Trabalhista e da Reforma da Previdência Social, com o aumento do tempo de trabalho para a aposentadoria e outras perdas de direitos historicamente conquistados pela luta das categorias. E certamente essas perdas aumentarão com o que está previsto na Reforma Administrativa - a PEC n ${ }^{\circ} 32 / 2020$.

Observa-se no discurso capitalista atual uma intimação no mundo do trabalho à gestão de si mesmo. E como sintoma desse imperativo sobre a autogestão notamos a autorresponsabilização. É importante, nesse sentido, atentar-se para esse discurso, tão propagado hoje pelas mídias que envolve o cuidado de si. Na contramão desse discurso, o que é proposto como este necessário "cuidado de si" é revestido da luta contra o modelo de gestão do capitalismo.

"Significando inicialmente administrar, dirigir, conduzir, o termo gestão remete atualmente a certo tipo de relação com o mundo, com os outros e consigo mesmo, da qual convém delinear os contornos" (GAULEJAC, 2020, p. 37). Esses contornos precisam ser bem destacados nessa luta. Para isso, é indispensável conhecer bem de que modo a gestão opera no território do trabalho docente, de que modo atua na relação que estabelecemos com o mundo, com os outros(as) e com nós mesmos(as).

Os diários colocam em destaque doenças físicas e psíquicas: estresse, angústia, trombose, dor de cabeça, deslocamento de mandíbula, enjoo, problema de voz, hipertensão arterial, problemas mentais. O estresse aparece como um grande vilão nesse território do trabalho docente. Em algumas situações, o(a) professor(a) solicita a mudança para outra escola, como aparecem em alguns diários. Há também casos de abandono da profissão, de desvio de função em que alguns/algumas professores(as) passam a ocupar funções em secretaria escolar, em bibliotecas, por exemplo. Os(as) que, mesmo acometidos(as) por alguma doença decorrente ou intensificada nesse contexto ficam no exercício docente, nem sempre conseguem manter-se em equilíbrio.

São narrativas que expressam como o sofrimento tem se ampliado na rede pública municipal de ensino de Valença. Narrativas de mal-estar docente, o qual se vincula aos fenômenos de precarização, intensificação e responsabilização. Esse sentimento de angústia 
crescente muitas vezes requer mecanismos de defesa que podem com o tempo levar o(a) docente ao isolamento.

A pesquisa apresenta duas linhas de ação de resistência frente a esses fenômenos: 1 . uma perspectiva da ação que é mais geral, na ordem da luta por políticas públicas que possam ir remodelando essa sociedade, com a garantia de melhores condições de vida - saúde, trabalho, segurança etc. -, que tem como referência um sindicato reinventado na atualidade; um sindicato fortalecido pelo coletivo docente, na contramão do que temos como imperativo do capitalismo financeiro. Um agir, portanto, situado no campo da dinâmica coletiva de enfrentamento e que está imbricado na ideia de uma aprendizagem a partir do que a doença - física, mental, social - diz sobre as condições de trabalho. Destaca-se nessa linha de ação, a necessidade de "[...] um melhor reconhecimento da ação sindical em nível mundial, continental e nacional" (GAULEJAC, 2020, p. 306) e local. Embora pensamos que aí - no âmbito sindical - também se faz imprescindível uma reinvenção capaz de mobilizar a criação de "dispositivos que protejam os trabalhadores diante dos efeitos nefastos da flexibilidade.” (Ibid., p. 306); 2. uma perspectiva de ação que começa de forma individual, pela assunção de que também se é responsável pela própria saúde, como um ato e performance de resistência, mas também como um modo de se constituir um coletivo de luta.

Indubitavelmente, a escrita de si, enquanto dispositivo da pesquisa (auto)biográfica, inscreve-se numa cultura do cuidado de si e em suas relações com a noção de conhecimento de si, através da qual acessa-se modos de reexistir no mundo da vida-profissão.

\section{Referências}

ABRAHÃO, Maria Helena Menna Barreto. Pesquisa (auto)biográfica - tempo, memória e narrativas. In: ABRAHÃO, Maria Helena Menna Barreto (Org.). A aventura (auto)biográfica: teoria \& empiria. Porto Alegre: EDIPUCRS, 2004. p. 201-224.

AMORIM-JUNIOR, Cléber Nilson. Segurança e saúde no trabalho: princípios norteadores. São Paulo: LTr, 2017.

APPLE, M. W. Poder, significado e identidade: ensaios de estudos educacionais críticos. Tradução de Ana Paula Barros e Cecília Mendes. Porto: Porto Editora, 2003.

ARAÚJO, Tânia Maria de.; PINHO, Paloma de Sousa; MASSON, Maria Lucia Vaz. Trabalho e saúde de professoras e professores no Brasil: reflexões sobre trajetórias das investigações, avanços e desafios. Cad. Saúde Pública, Rio de janeiro, 35, Suplemento 1, 2019, p. 1-14. Disponível em: https://www.scielo.br/pdf/csp/v35s1/1678-4464-csp-35-s1-e00087318.pdf. Acesso em: 26 set. 2020.

ARAÚJO, Tânia Maria de.; CARVALHO, Fernando Martins. Condições de trabalho docente e saúde na Bahia: estudos epidemiológicos. Educ. Soc., Campinas, V. 30, n. 107, p. 427-449, 
maio/ago. 2009. Disponível em: https://www.cedes.unicamp.br/publicacoes/edicao/83. Acesso em: 17 set. 2020.

ASSUNÇÃO, Ada Ávila.; OLIVEIRA, Dalila Andrade. Intensificação do trabalho e saúde dos professores. Educ. Soc., Campinas, vol. 30, n. 107, p. 349-372, maio/ago. 2009. Disponível em: http://www.cedes.unicamp.br. Acesso em: 12 maio 2020.

BARROS, Maria Elizabeth Barros de; HECKERT, Ana Lúcia Coelho; MARGOTO, Lilian. Trabalho e saúde do professor: cartografias no percurso. Belo Horizonte: Autêntica Editora, 2008.

CANDAU, Joël. Memória e identidade. Tradução de Maria Letícia Ferreira. $1^{\mathrm{a}}$ edição. $5^{\mathrm{a}}$ reimpressão. São Paulo: contexto, 2019.

CLANDININ, D. Jean; CONNELLY, F. Michael. Pesquisa narrativa: experiência e história em pesquisa qualitativa. Uberlândia: EDUFU, 2015.

CUNHA, Maria Teresa Santos. Do baú ao arquivo: escritas de si, escritas do outro. Revista Patrimônio e Memória. UNESP - FCLAs - CEDAP, v.3, n.1, 2007, p. 45-62. Disponível em: http://pem.assis.unesp.br/index.php/pem/article/view/8/455. Acesso em: 17 maio 2021.

DEJOURS, Christophe. A loucura do trabalho: estudo de psicopatologia do trabalho. São Paulo: Cortez - Oboré, 2002.

DELORY-MOMBERGER, Christine. A condição biográfica: ensaios sobre a narrativa de si na modernidade avançada. Natal, RN: EDUFRN, 2012.

DELORY-MOMBERGER, Christine. Biografia e educação: figuras do indivíduo-projeto. Natal, RN: EDUFRN, 2014.

DELORY-MOMBERGER, Christine. A experiência da doença: um tocar do existir. Revista da FAEEBA - Educação e Contemporaneidade, Salvador, v. 25, n. 46, maio/ago. 2016, p. 25-31. Disponível em: https://www.revistas.uneb.br/index.php/faeeba/article/view/2698 Acesso em: 15 set. 2020.

FOUCAULT, Michel. História da sexualidade 3: o cuidado de si. Tradução de Maria Thereza da Costa Albuquerque. 15 a edição. Rio de Janeiro/São Paulo: Paz e Terra, 2017.

GAULEJAC, Vicent de. Gestão como doença social: ideologia, poder gerencialista e fragmentação social. Tradução de Ivo Storniolo - Aparecida, SP: Ideias \& Letras, 2020.

GAULEJAC, Vicent de. La historia que heredamos: novela familiar y trayectoria social. Buenos Aires: Del Nuevo Extremo, 2018. Libro digital, EPUB.

HELMAN, Cecil G. Cultura, Saúde e Doença. Porto Alegre: Artmed, 2009.

HESS, Remi. Momento do diário e diário dos momentos. In: SOUZA, Elizeu Clementino; ABRAHÂO, Maria Helena Menna (orgs). Tempos, narrativas e ficções: a invenção de si. Porto Alegra: EDIPUCRS: EDUNEB, 2006. p. 89-103.

HYPÓLITO, Álvaro Moreira. Trabalho docente na educação básica no Brasil: as condições de trabalho. In: OLIVEIRA, Dalila Andrade. VIEIRA, Lívia Fraga. Trabalho na Educação Básica: a condição docente em sete estados Brasileiros. Belo Horizonte, MG: Fino Traço, 2012. p. 211-229.

HOLLY, Mary Louise. Investigando a vida profissional dos professores: diários biográficos. In: NÓVOA, António. Vidas de professores. 2a edição. Porto, Portugal: Porto Editora, 2007. p. $79-110$. 
JOSSO, Marie Christine. As narrações do corpo nos relatos de vida e suas articulações com os vários níveis de profundidade do cuidado de si. In: VICENTINI, Paula Perin; ABRAHÃO, Maria Helena Menna Barreto (orgs.). Sentidos, potencialidades e usos da (auto)biografia. São Paulo: Cultura Acadêmica, 2010a. p. 171-192.

JOSSO, Marie Christine. Experiências de Vida e Formação. Tradução de José Cláudio, Júlia Ferreira; revisão científica Maria da Conceição Passeggi, Marie-Christine Josso - 2.ed.rev. e ampl. Natal, RN: EDUFRN; São Paulo: Paulus, 2010 b.

JOVCHELOVITCH, Sandra; BAUER, Martin W. Entrevista narrativa. In: BAUER, Martin W.; GASKELL, George (orgs.). Pesquisa qualitativa com texto, imagem e som: um manual prático. Tradução de Pedrinho A. Guareschi. 13 ed. Petrópolis, RJ: Vozes, 2015. p. 90-113.

LEJEUNE, Philippe. O pacto autobiográfico: de Rousseau à internet. Tradução de Jovita Maria Gerheim Noronha e Maria Inês Coimbra Guedes. $2^{a}$ edição. Belo Horizonte: Editora UFMG, 2014.

MARCHESI, Álvaro; MARTÍN, Elena. Qualidade do ensino em tempos de mudança. Tradução de Fátima Murad. Porto Alegre: Artmed, 2003.

NÓVOA, António. Os professores e as histórias da sua vida. In: NÓVOA, António (org.). Vidas de Professores. $2^{\mathrm{a}}$ edição. Porto, Portugal: Porto Editora, 2007. p. 11-30.

OLINDA, E. M. B.; PINTO, E. C. B. O círculo reflexivo biográfico na pesquisa com jovens da periferia de Maracanaú-CE. Revista @mbienteeducação. São Paulo: Universidade Cidade de São Paulo, v. 12, n. 2, p. 263-286 mai/ago 2019. Disponível em: http://publicacoes.unicid.edu.br/index.php/ambienteeducacao/article/viewFile/718/675 Acesso em: 17 set. 2020 .

OLIVEIRA, Dalila Andrade; VIEIRA, Lívia Fraga. (Orgs). Trabalho docente na educação básica: a condição docente em sete estados brasileiros. Belo Horizonte: Fino Traço, 2012.

ORGANIZAÇÃO MUNDIAL DA SAÚDE. Dia Mundial da Saúde Mental 2017 - Saúde mental no local de trabalho. Disponível em: https:/www.who.int/mental_health/worldmental-health-day/2017/es/. Acesso em: 10 jan. 2019.

PASSEGGI, Maria da Conceição. Mediação biográfica: figuras antropológicas do narrador e do formador. In: PASSEGGI, Maria da Conceição; BARBOSA, Tatyana Mabel Nobre (orgs.). Memórias, memoriais e formação docente. Natal: EDUFRN; São Paulo: Paulus, 2008. p. 4359.

PASSEGGI, Maria da Conceição. Narrativas da experiência na pesquisaformação: 1 do sujeito epistêmico ao sujeito biográfico. Roteiro, Joaçaba, v. 41, n. 1, p. 67-86, jan./abr. 2016. Disponível em: Acesso em:< https://portalperiodicos.unoesc.edu.br/roteiro/article/view/9267/pdf $>$. Acesso em: 22 maio 2020.

PASSEGGI, Maria da Conceição; SOUZA, Elizeu Clementino de; VICENTINI, Paula Perin. Entre a vida e a formação: pesquisa (auto)biográfica, docência e profissionalização. Educação em Revista. Belo Horizonte. v.27, n.01, p. 369-386, abr. 2011. Disponível em: https://www.revistas.uneb.br/index.php/faeeba/article/view/382: Acesso em: 26 set. 2020.

PINEAU, Gaston. Temporalidades na formação: rumo a novos sincronizadores. São Paulo: TRIOM, 2004.

RAGO, Margareth. A aventura de contar-se: feminismos, escrita de si e invenções da subjetividade. Campinas, SP: Editora da Unicamp, 2018. 
RICOEUR, Paul. Narrative Identity. Philosophy Today, 35:1, p. 73-81, 1991. Disponível em: <https://pt.scribd.com/doc/24868946/Paul-Ricoeur-Narrative-Identity>. Acesso em: 27 out. 2017.

RICOUER, Paul. Identidade frágil: respeito pelo outro e identidade cultural. Disponível em: https://www.uc.pt/fluc/uidief/textos_ricoeur/identidade_fragil?web=1\&wdLOR=c5C22EB3267C7-47F4-9831-7CC1D8FE817D. Acesso em: 17 maio 2021.

RICOUER, Paul. Compreensão de si e história. Disponível em: https://www.uc.pt/fluc/uidief/textos_ricoeur/autocomprehensio_et_histoire?web=1\&wdLOR= cE2C0DAAA-925B-495E-9D63-F1B84E6346A1. Acesso em: 17 maio 2021.

RICOEUR, Paul. Tempo e narrativa 1: a intriga e a narrativa histórica. Tradução de Claudia Berliner. $2^{\mathrm{a}}$ tiragem. São Paulo: Editora WMF; Martins Fontes, 2012a.

RICOEUR, Paul. Tempo e narrativa 3: o tempo narrado. Tradução de Claudia Berliner. $2^{\text {a }}$ tiragem. São Paulo: Editora WMF; Martins Fontes, 2012b.

RICOEUR, Paul. Percurso do reconhecimento. Tradução de Nicolás Nyimi Campanário. $2^{\mathrm{a}}$ reimpressão. São Paulo: Edições Loyola, 2017.

RICOEUR, Paul. O si-mesmo como outro. Tradução de Ivone C. Benedetti. $2^{a}$ tiragem. São Paulo: Editora WMF; Martins Fontes, 2019.

SOUSA, Rosiane Costa de. Refigurar a vida-profissão: (auto)biografia, condições de trabalho e adoecimento. 2021. 297f. Tese (Doutorado) - Programa de Pós-graduação em Educação e Contemporaneidade, Departamento de Educação, Universidade do Estado da Bahia, Salvador, 2021.

SOUZA, Elizeu Clementino de. Histórias de vida, narrativas, conhecimento de si, representações da docência. In: ABRAHÃO, Maria Helena Menna Barreto (Org.). A aventura (auto)biográfica: teoria \& empiria. Porto Alegre: EDIPUCRS, 2004. p. 387-417.

SOUZA, Elizeu Clementino de. O conhecimento de si: estágio e narrativas de formação de professores. Rio de Janeiro: DP\&A; Salvador: UNEB, 2006.

SOUZA, Elizeu Clementino de; CORDEIRO, Verbena Maria Rocha. Histórias a contrapelo: escritas de si, (auto)biografia e formação de leitores. Anais. Colloque international (19862007): Le biographique, la réflexivité et les temporalités- Articuler langues, cultures et formation,Tours/França, 2007. Disponível em: http://alb.org.br/arquivomorto/edicoes_anteriores/anais16/sem07pdf/sm07ss07_04.pdf. Acesso em: 17 maio 2021.

SOUZA, Elizeu Clementino de. Diálogos cruzados sobre pesquisa (auto)biográfica: análise compreensiva-interpretativa e política de sentido. Educação. Santa Maria| v. 39 | n. 1 | p. 3950 | jan./abr. 2014 | educação. Disponível em: http://dx.doi.org/10.5902/1984644411344. Acesso em: 17 maio 2021.

SOUZA, Elizeu Clementino de. Existir para resistir: (auto)biografia, narrativas e aprendizagens com a doença. Revista da FAEEBA - Educação e Contemporaneidade, Salvador, v. 25, n. 46, p. 25-31, mai./ago, 2016. Disponível em: <https://www.revistas.uneb.br/index.php/faeeba/article/download/2698/1827>. Acesso em: 15 mar. 2017.

SOUZA, Elizeu Clementino de. O que será que será? Estigmas, refiguração identitária e narrativas biográficas. In: SOUZA, Elizeu Clementino de; VICENTINI, Paula Perin; LOPES, Celi Espasadin. Vida, narrativa e resistência: biografização e empoderamento. Curitiba: CRV, 2018. p. 43-62. 